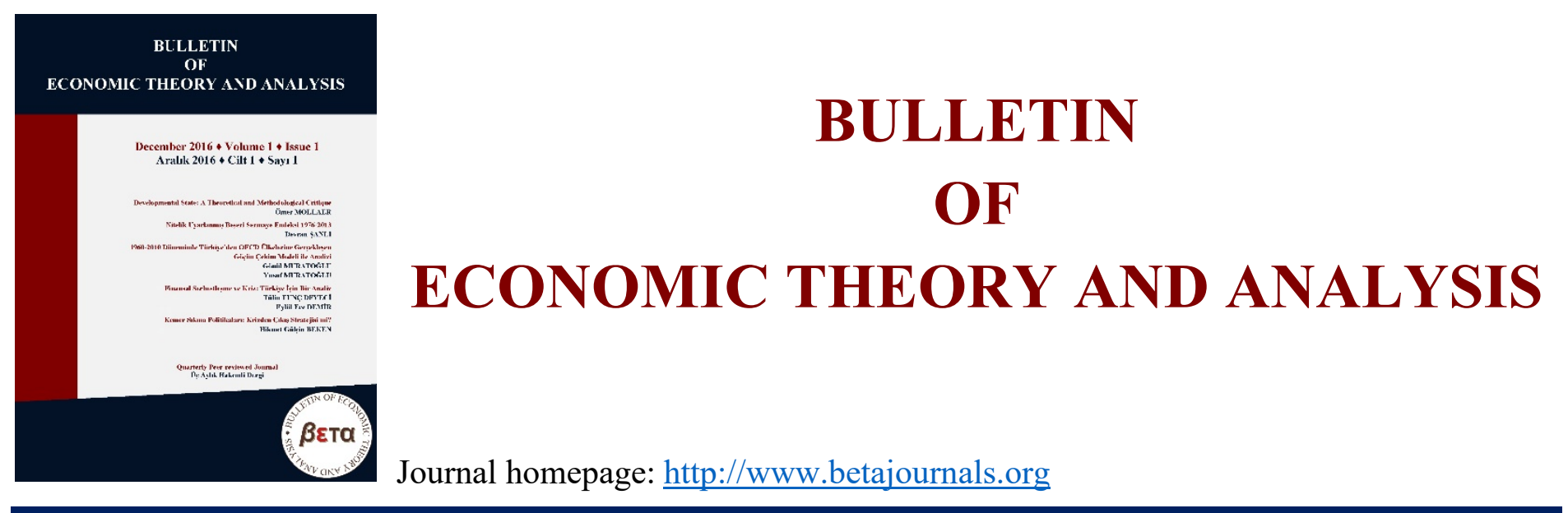

\title{
Structural Change and Growth Prospects in the Turkish Manufacturing Industry
}

\section{İsmail TUNCER $\odot \underline{h t t p s: / / o r c i d . o r g / 0000-0003-0180-7415 ~}$}

\section{Maya WAFEK MOALLA @}

To cite this article: Tuncer, İ., \& Moalla, Wafek, M. (2020). Structural Change and Growth Prospects in the Turkish Manufacturing Industry. Bulletin of Economic Theory and Analysis, 5(1), 1-19.

Received: 29 Jan 2020

Accepted: 06 Jun 2020

Published online: 30 Jun 2020

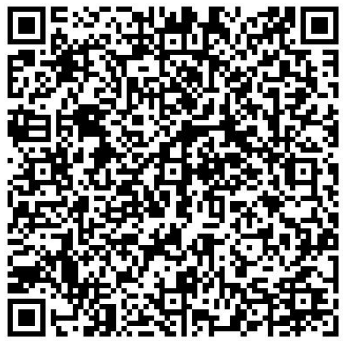




\title{
* BETd 空 \\ Bulletin of Economic Theory and Analysis
}

Volume V, Issue 1, pp. 1-19, 2020

http://www.betajournals.org

Original Article / Araştırma Makalesi

Received / Alınma: 29.01.2020 Accepted / Kabul: 06.06.2020

\section{Structural Change and Growth Prospects in the Turkish Manufacturing Industry İsmail TUNCER ${ }^{\mathrm{a}}$ Maya WAFEK MOALLA ${ }^{b}$}

${ }^{a}$ Prof. Dr., Mersin University, FEAS, Department of Economics, Mersin, TURKEY@https://orcid.org/0000$\underline{0003-0180-7415}$

${ }^{\mathrm{b}}$ Mersin University, FEAS, Department of Economics, Mersin, TURKEY॰ https://orcid.org/0000-0003-4076$\underline{2790}$

\begin{abstract}
The growth and development literature emphasize two sources of labor productivity growth. First, productivity improvements triggered by physical and human capital accumulation and technological change and second, productivity improvements arising from movements of resources towards high productivity industries, that is structural change. The effect of structural change may be productivity enhancing or may bring a drag on aggregate productivity. Empirical studies highlight growth enhancing structural change for newly industrialized Asian countries while indicates weak or growth reducing structural change for some Latin American and African countries. Moreover, these studies also highlight the importance of movements of resources within the manufacturing sub industries. The process of structural change and economic development of developed countries is well documented but studies about less developed or developing countries is very weak. In this respect this study aims to examine whether the Turkish economy fits into this picture of growthenhancing or reducing structural change? The conventional shift-share analysis is used in order to analyze the effect of structural change on the productivity of the manufacturing industry and the whole Turkish economy for the period of (20032017). The results suggest that on average, the within growth effect dominates labor productivity improvements whereas between growth and covariance effects account for very small parts of productivity growth for all the periods.
\end{abstract}

Anahtar Kelimeler Growth, structural changes, Productivity, Turkey, Shift-share analysis.

JEL Kodu J21, R11, O40.

CONTACT İsmail TUNCER, $\bowtie$ ismailtuncer@gmail.com $\triangleq "$ Mersin University, FEAS, Department of Economics, Mersin, TURKEY 


\section{Introduction}

Structural change has always been a central feature of economic development. Today's developed countries are those undergo a successful process of structural change in transforming their structure from resource based low productivity activities to high productivity sectors. Although structural transformation is a very complex and multifaceted phenomenon, economic research usually focused on sector composition of output and employment. Developing countries need to move from low value-added to higher value-added and from lower-productivity to higherproductivity sectors, industries and economic activities in order to transform their structure and provide more welfare to their citizens.

From theoretical point of view, the process of structural change is shaped by the interaction of both supply and demand forces. On the supply side, productivity differentials among industries driven by technological progress, determines the evolution of the output and employment shares of different industries. Improvement in technology leads to produce better goods with less input usage which pave the way for increasing productivity. On the demand side of the picture, differences mainly in relative prices and preferences of goods produced by different industries determines the volume and composition of demand for output of these industries. In other words, demand determine the direction of change that is which industries would grow fast and which of them would be stagnated. Studies that review the theoretical and empirical literature reach the conclusion that, interactions of technological progress on the supply side and preferences and relative prices on the demand side determines the speed and direction of the structural change process. ${ }^{1}$

To elaborate on the relationship between structural change and productivity growth many different models are developed in the literature. Review of these models are beyond the scope of this study. In order to understand the main driving forces behind structural change according to these models, only few outcomes of them are mentioned. Engel's law suggests a lower income elasticity of demand for goods of the traditional sector compare to modern manufacturing and that induce workers to move from the low productivity to high productivity sector. If a small open economy is considered, relative prices are determined in the world markets, then comparative advantage of the economy may shift to the traditional sectors. Change in the structure of the

\footnotetext{
${ }^{1}$ For an in-depth review of this literature see, Krueger (2008) and Baily, Bartelsman and Haltiwanger (2001).
} 
economy may enhance productivity growth. The movement of labor from the traditional to modern sector leads to an increase in the productivity of both sectors due to high potential of learning by doing in the modern sector. In this respect, productivity growth and structural change may reinforce each other, productivity growth may cause more structural change in the economy which in turn lead to more productivity growth. But a vicious circle of growth and poverty also possible in case of lower productivity improvements and structural change (Matsuyama, 2008)

Another supply side driver of structural change may be the substitutability between production inputs. For example, when GDP per capita is relatively low, then scarcity of capital will raise the output price of the sectors with low elasticity of substitution between capital and labor. The decrease in relative price leads to reallocation of resources towards the industries with low substitution elasticity (Alvarez-Cuadrado, Van Long \& Poschke, 2017). Moreover, some studies point out that the variations in labor-augmenting technological progress are the dominant element behind structural transformation. Whereas the differences in the capital shares give rise to the reallocation from agriculture to manufacturing and from manufacturing to services, the differences in the elasticity of substitution are slightly reduce the differences in capital shares (Herrendorf, Herrington \& Valentinyi, 2015).

Majority of research about structural change focused on the supply side but both supply and demand forces determine the relative prices which leads to reallocation of the resources among different activities. Some research has been focused on the differences in the demand structure as a determinant of structural change. Starting from the Engel's law and assuming that income elasticity of demand for manufacturing goods is less than one but income elasticity of services is greater than one, as welfare rises overtime the share of services in overall final demand will increase and that of manufacturing expected to decrease. This is usually known as the "hierarchy of needs hypothesis", the share of services in households demand has been rising substantially over time. However, the hypothesis was empirically challenged by some studies (see. Summers, 1985).

The theoretical literature emphasized the main sources of structural change as income, input substitutions and technological improvements over time. Likewise, empirical studies show that the manufacturing sector can be a promoter in changing the economic structure from an agrarian society towards an industrial one. At lower incomes, the application of low capital-intensive technologies allows for improvements in both productivity and employment. As the capital 
intensity of technology increases, productivity gains dominate and employment shifts towards manufacturing and other related services. For developing countries intended to maintain growth while creating sustainable jobs, manufacturing offers an opportunity not only to re-balance the economy towards higher value-added sectors but also to provide a relatively wide employment base with higher labor productivity (UNIDO, 2013).

The contribution of structural change to aggregate productivity growth has been well documented for developed, while only few empirical studies have been done for developing countries. To fill this gap, some new studies have been carried out about structural change in developing countries. For example, a collection of case studies about structural transformation in some Asian, African and Latin American developing countries were recently published as an edited book by Rodrik, McMillan \& Sepulveda (2016). The results of these and other case studies broadly decomposed economic growth based on fundamentals (Latin American case), growth driven by structural change (African case) and growth that based on both fundamentals and structural change concurrently (only in East Asia). This literature suggests that, during the development process within sector productivity growth and productivity enhancing structural change must go hand in hand. With this respect, we try to fill at least a small part of this gap about structural transformation in the Turkish Economy.

Turkey followed an inward oriented or import substitution strategy of development beginning in late 1950's. In the first stage of import substitution policies, production oriented towards replacing the imports of non-durable consumer goods. This strategy enabled the Turkish economy to embark upon a process of industrialization that generating substantial production capacity till the mid 1970's. The first stage of import substitution smoothly proceeded until the end of 1960's with concrete 6 to 7 percent growth of real GNP. Then, Turkey faced with the choice of either moving on to the second stage of import substitution or outward oriented strategy based on exporting the already produced manufactures. Turkey opted to move on the second stage of import substitution strategies which aimed to domestically produce and replace imported durable consumer and capital goods. Naturally, this stage requires more import of specialized inputs and technology which considerably raised foreign exchange requirements. This met with the petroleum price hikes that lead to a balance of payment crises in mid-1977. Thus, the Turkish economy ran into a serious foreign debt crisis during 1978-1980. Although, the foreign debt indicators were moderate, the time composition of its external debt had intensified the debt servicing problem. 
However, the Turkish economy had been forced to introduce a new structural adjustment program (SAP) along the lines approved by the IMF and the World Bank in 24 January 1980. Starting with that program, Turkey implemented a wide range of reforms including liberalization of external trade, relaxation of the tariff system, deregulation of the financial system and foreign investment regulations (Balkır, 1993: 101-103).

In the initial phase (1980-1983) of the structural adjustment program (SAP), a stabilization package was implemented, and some steps were taken to transform the economy into an outward oriented free market economy. In doing so, price controls removed, moderate price stability was achieved and supports of agriculture was gradually reduced. After 1983, the structural adjustment phase of the program had been applied. The financial sector deregulated, the relative share of the government in productive activities reduced via privatization of the state-owned enterprises and the catalyzing role of foreign capital were emphasized by encouraging foreign capital inflows.

Towards the 1990's, the momentum of the reforms was in decline after a decade of rapid economic growth. Turkey undertook capital market liberalization in 1989 because the Turkish government was conceived large inflows of capital as a key mechanism to restore economic growth. Liberalizing the capital account without taking into consideration the internal and external macroeconomic imbalances pave the way to the subsequent economic crisis. In other words, "...Turkey was able to evade a crisis at the end of the 1980s, but at the expense of a highly fragile pattern of debt-led economic growth - which resulted in successive financial crises in the post 1990's" (Öniş \& Rubin, 2004: 6-7). Following the capital account liberalization and high interest rates relative to developed countries, large volumes of financial capital moved into the Turkish economy. These capital inflows led to stock market booms and helped to finance the current account and the budget deficits. However, this external financial liberalization leads to increase in the debt of the private sector and, also increase the cost of borrowing for the government.

All these developments have been made the economy more fragile and prone to economic crises. The economic crises resulted in a profound loss of economic activity and employment as well as a reduction in welfare. The more recent crises seem to be much more widespread that impacts every facets of economic life of the firms and the households in the economy. The crisis (April 1994 and February 2001) that suffered after liberalization of the external financial sector was initiated by sharp capital outflows from the country. That led to fast collapse of the financial 
markets. Then, the effects of the crises spread quickly from the financial sector to the real sector of the economy. In short, economic liberalization policies have led to escalation of volatility in the economy which in turn resulted in economic crises followed by higher unemployment and growing external debt. Dependence on volatile short-term capital inflows, investment inefficiency and short run macro policies negatively impacts on structural transformation of the economy from activities of low productivity to high (Öniş \& Şenses, 2010: 2-6). Briefly, starting from the end of 1970's, Turkey initiated and applied enormous structural and other economic reforms in the economy. During the last three decades, the Turkish economy has experienced important structural changes and become more integrated with the global economy. All these changes must have some effects of productivity improvements.

In this paper, the effects of the within industry productivity growth and structural change on aggregate labor productivity growth are analyzed for the manufacturing industries in Turkey. There exist many theoretical and empirical arguments in favor of the manufacturing industry as the main engine of sustainable growth (Szirmai, Naudé \& Alcorta, 2013). Manufacturing industry has been considered as the "growth enhancing" sector since it absorbs resources from low-productive activities -with limited opportunities for technological change and value added gains- such as rural agriculture or urban informal services; the matter that stimulates the process of structural change which is the core feature of the modern economic growth (McMillan \& Rodrik, 2011). This study also decomposes aggregate labor productivity growth for the main sectors (A21) of the whole Turkish economy. In this respect, the traditional shift share analysis was employed in decomposing aggregate productivity growth into "within sector" productivity growth, "static structural change" and "dynamic structural change" effects. The rest of the paper structured as follows. In section 2 a brief review of the literature is given, Section 3 reviews the data and the methodology, section 4 is about evaluating the results and conclusion.

\section{Structural Change and Economic Growth}

The search for sustained economic growth has been the most interesting topic for economists all around the world since the early works of Adam Smith. Economic growth is essentially associated with the process of structural change. But in the second half of the $20^{\text {th }}$ Century and during the first decade of the $21^{\text {st }}$ Century, structural change has been ignored or at least taken as given in much of the growth and development research (Syrquin, 2010). However, 
structural change is a fundamental and integrated component of economic growth and development. The countries that remain poor have been unable to shift away from traditional sectors to the modern sectors. In other words, "All countries that remain poor have failed to achieve structural change, that is, they have been unable to diversify away from agriculture and the production of traditional goods into manufacturing and other modern activities" (Lin, 2012).

From theoretical point of view sector specificity would be the main determinant of growth and structural change. Traditional growth theories are activity or sector- neutral - in the sense that effects of a unit of value added on growth do not depend on the sector or activity in which that unit of value is created. So, any change in composition of economic activity would have no implications on its growth prospects. For example, in the Solow-Swan type neo-classical growth models, the main sources of output growth per worker are accumulation of capital per worker and exogenous technological progress. Since capital accumulation ultimately is subject to diminishing returns, in the long run the output per worker can only be sustained with improvements in technology. The impact of structural change on growth is completely ignored. Subsequently, some two sector growth models developed and used in the analysis of growth and structural change. On the other hand, if growth is assumed to be sector- specific, then a change in composition of the industries could affect economic growth. The structuralists and researchers within the Kaldorian tradition take such a view and paved the way for research about structural change and the importance of manufacturing as an engine for growth and development. In this line of economic research, growth is not sector or activity neutral, it is sector specific. The manufacturing industry is thought to have some superior properties that make it special for growth prospects. Usually these properties are summarized as, benefitting from increasing returns and positive external economies, a larger room for learning by doing, linkages with other parts of the economy and building technological capabilities. All these special characteristics provides the manufacturing sector to be driving horse for growth in the medium and long run. ${ }^{2}$

As we mentioned above, structural change starts recently to appear in a number of studies about developing countries which witnessed a decreasing agriculture's share of GDP from 40 percent in 1950 to just 16 percent in 2005; but a temporally increasing manufacturing's share of

\footnotetext{
${ }^{2}$ For more detail about theoretical and empirical underpinnings see Tregenna (2014) and Szirmai (2012).
} 
GDP from 12 percent in 1950 to about 17 percent in the early 1980s. Turkey, for example, showed a significance decrease in agriculture's share of GDP from 49 percent in 1950 to 5,8 percent in 2018 and in turn, an increase in the manufacturing's share of GDP from 11 percent in 1950 to 19 percent in 2018 .

Structural change and economic development are strongly interrelated. Countries at different stages of development have comparative advantages in different industries. At low income levels, the relative share of the agricultural sector is more significant in GDP and employment compare to manufacturing and services. As income rises, traditional sectors' share of GDP shrinks dramatically concurrently with an inverted $U$ curve in the manufacturing sector and increasing in the share of services. As countries become richer, the natural resource endowments and the population size play a dominant role in the reallocation of resources among industries. Natural resource-rich countries have witnessed corroded manufacturing's shares leading to the "natural resource curse"3 or "Dutch disease" (Sachs \& Warner, 2001). However, the matter is different for the large economies in which manufacturing sector has a much higher share of GDP due to their larger domestic markets.

The patterns of structural changes can be noticed also by looking at the changing significance of the economic sectors at different moments of time. The importance of manufacturing sector in China, Indonesia, the Republic of Korea, Malaysia and Thailand, for instance, has been increased from 14 percent in 1950 to 25 percent in 2005. But an inverted Ushaped curve has described the relationship between manufacturing' output share and GDP per capita in Argentina, Brazil and Mexico. Even with initially similar stages of development, the structural and compositional heterogeneities will be seen after a certain time period such as the case of the Republic of Korea and Ghana. Although that they had quite similar structures in the 1950's; their structures had varied completely. The Republic of Korea decreased agriculture's share by increasing that of manufacturing, but in Ghana the agricultural sector persisted to have the largest share.

\footnotetext{
${ }^{3}$ The resource curse concept explains the causal relationship between the endowment of abundant natural resources and poverty. It means that some countries are poor despite of their rich natural resources.

${ }^{4}$ The Dutch disease refers to the negative impact of the currency appreciation caused by resource revenue on the competitive position of other industries.
} 
Promoting structural change can be anticipated through the industrial policies that are expected to offer better prospects of economic growth. These policies attempt to develop the economic structure such as those on trade, competition, foreign direct investment and the exchange rate. Following the financial crisis of 2001 under the auspices of the IMF and the World Bank, the Turkish government designed a new economic program that aims to fix the ruins in the banking system, stabilize the budget and provide a new anchor for price stability. In the aftermath of the 2001 financial crisis, the Turkish economy benefits from five to six years of rapid economic growth driven by productivity growth and structural change. For instance, the state oversees close coordination with policies such as increasing capital flows into emerging markets, strengthening the regulatory infrastructure, the independence of the Central Bank and the improving the organizational performance through transparency and privatizations which attract more foreign direct investment during 2001-2007.

The reforms that above mentioned, initiated after the 2001 crisis under auspices of the IMF and the World Bank gradually came to be reversed in the aftermath of the 2008 Global Financial Crisis. In most case a rule based existing policy framework was increasingly shifting back towards discretion, the macroeconomic framework also deteriorated, as reflected by low or negative real interest rates while the economy was booming. This low-quality growth also led to a relatively large current account deficit and an inflation rate stuck at high single-digits, markedly higher than Turkey's trade partners (Acemoğlu \& Üçer, 2015).

Shortly, Turkey undertook tremendous economic reforms over the past four decades. There has been a shift from agriculture towards industry and services. These economic reforms have successfully achieved some of their main goals. The economy has experienced rise in export competitiveness, diversification of economic activities, and a shift towards more productive manufacturing and related service industries. The economy has become more integrated with the global financial and goods markets. However, these accomplishments have not been enhanced with robust productivity growth and that bring a drag on aggregate productivity growth. This study try to examine the effects of structural change on aggregate productivity growth in both manufacturing industries and the whole economy. 


\section{The Data and Methodology}

In this study, we make use of the Turkish Statistical Institute (TURKSTAT) data of economic activities classified according to the Statistical Classification of Economic Activities in the European Community (NACE Rev.2) for the period of 2003-2017. We compile and use the industry and services statistics, national accounts database and producer prices data of the TURKSTAT in the analysis. Three variables from the databases are utilized, namely value-added in factor prices (VA) and the number of persons employed. The value-added figures are deflated by the relevant industrial Producer Price Indices (PPI) and sectoral GDP deflators.

From the empirical case studies of developing and developed countries, we can reach the conclusion that within sector productivity growth and structural change must go hand in hand during the development process (Mcmillan \& Rodrik, 2011). Combining the within and between growth effects would help achieving feasible and rapid growth by ensuring the rapid flow of resources toward high productivity sectors along with accumulation of the necessary skills, knowledge and other capabilities. Any policy that improves one of them is good for the other. However, this relationship is not unconditional. Simply, it is possible to make noticeable structural transformation without corresponding progresses in fundamentals, and vice versa. On the other hand, investing in fundamentals may not be accompanied by desirable structural changes.

Figure 1 depicts the correlation between (end year) relative sectoral productivity in log scale and changes in employment shares in the Turkish Manufacturing (2 digit) Industries (2003-2017). The dynamic industries that are more productive and increased their employment share are: transport equipment (29), other transport equipment (30), basic metals (24), paper and paper products (17) and electrical equipment (27). However, the employment share of these industries in total manufacturing is too low and overall, only around $13.2 \%$ of total manufacturing employment. 


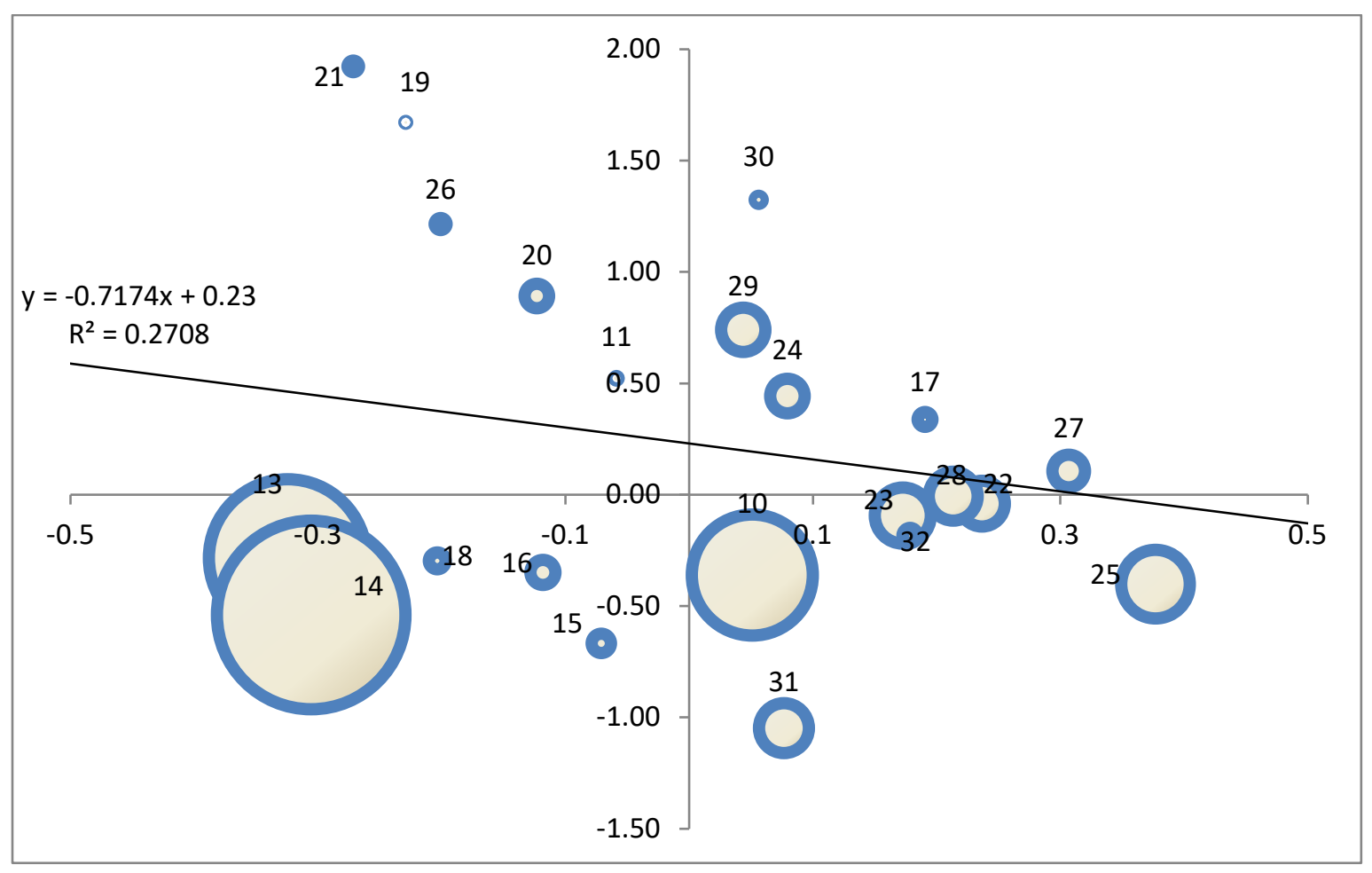

Figure 1. Correlation between sectoral productivity and changes in employment shares in the Turkish Manufacturing Industries (2003-2017)

Note: The size of the circles represents employment shares in the initial year (2003). The line represents fitted values of a linear regression of changes in sectoral productivity to total productivity by changes in employment shares.10= food, $11=$ beverage, $12=$ tobacco, $13=$ textiles, $14=$ clothing, $15=$ leather, $16=$ wood, $17=$ paper and paper products, $18=$ recorded media, $19=$ coke and refined petroleum, $20=$ chemicals, $21=$ pharmaceuticals, $22=$ rubber and plastics, $23=$ non-metallic minerals, $24=$ basic metals, $25=$ fabricated metal products, $26=$ computer, electronic and optical products, $27=$ electrical equipment, $28=$ manufacturing n.e.c, $29=$ transport equipment, $30=$ other transport equipment, $31=$ furniture, $32=$ other industries, $33=$ Other manufacturing, and repair and installation of machinery and equipment.

The sub-industries that have a decline in employment shares and accompanying negative productivity growth are, textile (13), clothing (14), leather (15), wood (16) and recorded media (18). Interestingly, the employment share of these low productivity industries in total manufacturing is around $40.5 \%$. Industries with above average productivity but that reduce their employment shares are, beverages (11), tobacco (12), coke and refined petroleum (19), chemicals (20), pharmaceuticals (21), computer and electronic and optical products (26). The employment share of this group is only $6.4 \%$ of total manufacturing employment at 2003 and this share has declined to 4.7 at 2017 . Overall, $80 \%$ of the manufacturing employment is in industries with below average productivity. Only around $20 \%$ of the employment in manufacturing are in high productivity sectors and only $13.2 \%$ of this employment are in dynamic industries that increase their employment share and has above average productivity. Looking across manufacturing 
industries, the general relationship is negative indicating that growth in employment stemmed from low productivity industries between 2003 and 2017. From this basic representation of the raw data can be concluded that the contribution of structural change to aggregate manufacturing productivity seems to be very trivial if not negative.

After these preliminary results of Figure 1, the "structural bonus and/or burden" hypothesis is being examined. The structural bonus hypothesis postulates a positive relationship between structural change and economic growth; in other words, "structural bonus and burden" hypothesis states that; the shift of the labor resources from low to high productivity (usually high capital intensity) industries, then these shifts will drive economic growth.

Aggregate labor productivity (LP) at time $\mathrm{t}$ can be written as:

$L P^{t}=\sum_{i=1}^{n} \frac{Y_{i}^{t}}{L_{i}^{t}} \frac{L_{i}^{t}}{L^{t}}=\sum_{i=1}^{n} L P_{i}^{t} S_{i}^{t}$

Where, subscript $i$ denotes manufacturing sub industries $(i=1, \ldots n), S i$ the employment share of (sub) industry $i$ in total manufacturing employment, Y real value-added and L employment of the (sub) industry.

Taking the first difference of equation 1 above and dividing both sides by $L P^{\text {by }}$ :

$$
\begin{aligned}
& \frac{L P^{f y}-L P^{b y}}{L P^{b y}}= \\
& \sum_{i=1}^{n} \frac{\left(L P_{i}^{f y}-L P_{i}^{b y}\right) S_{i}^{b y}}{L P^{b y}}+\sum_{i=1}^{n} \frac{\left(S_{i}^{f y}-S_{i}^{b y}\right) L P_{i}^{b y}}{L P^{b y}}+\sum_{i=1}^{n} \frac{\left(S_{i}^{f y}-S_{i}^{b y}\right)\left(L P_{i}^{f y}-L P_{i}^{b y}\right)}{L P^{b y}}
\end{aligned}
$$

Where, $L P$ is the labor productivity in the total manufacturing sector, $L P i$ is the labor productivity of industry $i$ and $S i$ is the employment share of sector $i$ in total manufacturing industry. The final year is denoted by $f y$ and by represents the base year. The term on the left-hand side of equation (2) is the aggregate labor productivity growth of the whole manufacturing industry. The first term on the right-hand side of equation (2) represents the within sector growth effect, while the second and the third terms are the effects of structural change on aggregate productivity growth. The second term is the static and third term represents the dynamic shift effect of structural change. 
The first term that reflects the within (sector) effect can be defined as the sum of labor productivity changes of industries weighted by the base year employment share of the industries. In fact, it is the contribution of productivity growth within the individual sectors to overall labor productivity growth. The second term, namely the static shift effect, can be defined as the contribution of changes in the employment shares of the industries, with different productivity levels, to overall productivity growth. It will be positive if high productivity industries attract more labor resources, and it will be negative if high labor productivity industries attract less labor resources. That is, the "structural bonus and burden" hypothesis expects a positive contribution of the static shift effect. That means that: $\left(S_{i}^{f y}-S_{i}^{b y}\right) L P_{i}^{b y}>0$. The dynamic shift effect can be defined as the contribution of the interaction between changes in employment shares and productivity improvements of the industries to overall productivity growth. It will be contributed positively to the aggregate labor productivity growth if labor force shifts towards industries that improve their productivity. If the term $\left(S_{i}^{f y}-S_{i}^{b y}\right)\left(L P_{i}^{f y}-L P_{i}^{b y}\right)$ is positive, the dynamic shift effect is expected to positively contribute aggregate productivity growth. Empirical studies usually report very small or negative contribution of dynamic shift effect to aggregate productivity growth.

The shift share decomposition approach has been used in this work in order to derive a deeper understanding of the sources of productivity growth in the Turkish manufacturing industry during the whole period of 2003-2017 and the sub-periods of 2003-2008 and 2010-2017 from one side and on the other one, the whole economy during the whole period of 2004-2017 and the subperiods of 2004-2008 and 2010-2017. For the whole economy there is only employment data for 9 industries with different classification for the year 2003. For that reason, the period of analysis shortened to 2004-2017 for the whole economy. The first column of Table (1) shows the annual growth rate of labor productivity in the Turkish manufacturing industries for the periods of 20032008, 2010-2017 and 2003-2017. The other columns indicate the within effect, the static and the dynamic shift effects, respectively. 
Table 1

Decomposition of Labor Productivity in Turkish Manufacturing Industries

(Average annual growth rates)

\begin{tabular}{cccccc}
\hline & $\begin{array}{c}\text { Productivity's } \\
\text { growth rate }\end{array}$ & $\begin{array}{c}\text { Within sector } \\
\text { effect }\end{array}$ & $\begin{array}{c}\text { Static shift } \\
\text { effect }\end{array}$ & $\begin{array}{c}\text { Dynamic shift } \\
\text { effect }\end{array}$ & Total effect \\
\hline $2003-2008$ & -2.42 & -2.58 & 0.12 & 0.04 & -2.42 \\
$\%$ & & 106.8 & -5.1 & -1.7 & 100.0 \\
$2010-2017$ & 5.87 & 6.29 & -0.11 & -0.30 & 5.87 \\
$\%$ & & 107.0 & -1.8 & -5.2 & 100.0 \\
$2003-2017$ & 1.84 & 2.44 & 0.00 & -0.61 & 1.84 \\
$\%$ & & 132.7 & 0.2 & -32.9 & 100.0 \\
\hline
\end{tabular}

Source: Authors' calculations with the data of the Turkish Statistical Institute.

In the period of 2003-2008, the annual average growth of aggregate labor productivity in manufacturing industries of the Turkish economy was negative $(\%-2.42)$ and the source of this drag on productivity is the within growth effect. The effect of the static and dynamic shift effect is positive but negligible. ${ }^{5}$ On the other hand, the growth rate of labor productivity in the Turkish manufacturing industries during the period 2010-2017 is $5.87 \%$ and the basic source of this productivity improvements originated from the within industry effect, the effect of structural change is negative but trivial. In the whole period of 2003-2017, annual growth of labor productivity is $1.84 \%$. Shortly, productivity improvements in the Turkish manufacturing industries comes mainly from the within sector productivity improvements. These results are in line with the results of other empirical studies. For example, the results of the study by Tuncer \& Alt1ok (2013), structural change has made a very little contribution (positive or negative) to the overall growth in labor productivity in Turkey. Similar to other studies, we find that the within-sector effect typically was the main driving source of labor productivity improvements in manufacturing industries of the Turkish economy.

The trivial effects of structural change on labor productivity in the manufacturing industry led us to focus on the effect of structural change on the aggregate labor productivity growth of the whole Turkish economy. Figure (2) depicts the correlation between (end year) relative sectoral

\footnotetext{
${ }^{5}$ One explanation for low or negative productivity growth comes from capabilities approach. Earlier privatization attempts of the state-owned enterprises had not gain considerable progress because of legal and political barriers. However, in all recent attempts of privatization, the fundamental goals of privatization, like efficiency and productivity enhancements, protecting consumers and flourishing a competitive environment, were abandoned (See, Atiyas, 2010).
} 
labor productivity and change in employment share between 2004 and 2017. In this period, low productivity sectors agriculture and other services $(\mathrm{S}+\mathrm{T}+\mathrm{U})$ witnessed the largest drop in employment share. The employment share of the wholesale and retail trade $(\mathrm{G})$, transportation and storage $(\mathrm{H})$ also experience a decline in this period, despite being slightly above average in labor productivity. Service industries were expanded but remained to be low-productivity industries. The manufacturing sectors witnessed a small decline in their employment share and had relatively high productivity. A larger proportion of employment share and economic growth emerged from construction $(\mathrm{F})$, utilities $(\mathrm{D}+\mathrm{E})$ and real estate services. Looking across sectors, the general relationship is positive indicating that growth in employment was occurring in sectors that have raising productivity between 2004 and 2017.

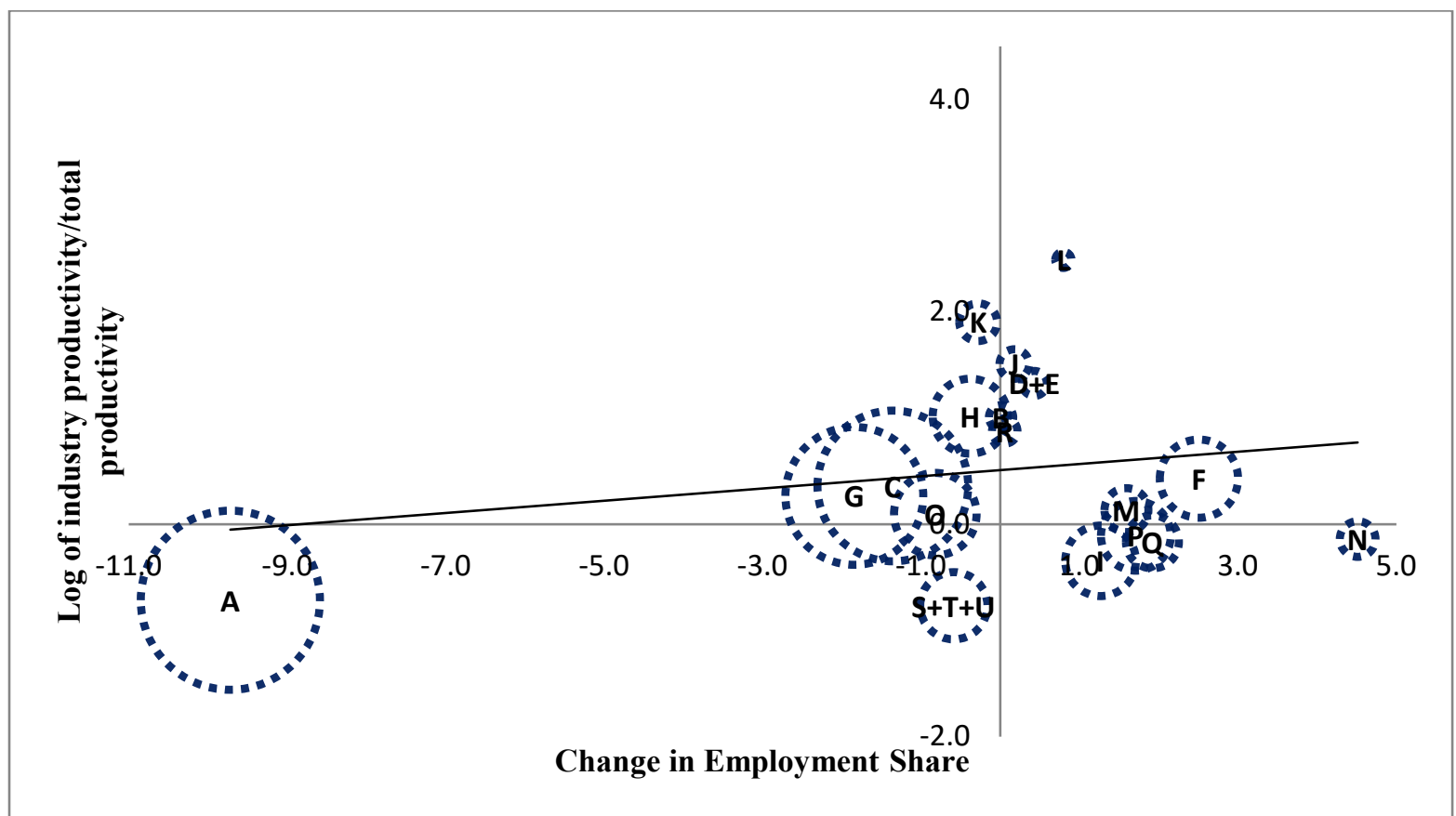

Figure 2. Correlation between sectoral labor productivity and changes in employment shares in the Turkish Economy (2004-2017)

Source: Authors' calculations with the data of the Turkish Statistical Institute.

Note: The size of the circles represents employment shares in the initial year (2004). The line represents fitted values of a linear regression of changes in (end year) relative sectoral productivity to total productivity by changes in employment shares. $\mathrm{A}=$ agriculture, $\mathrm{B}=$ mining and quarrying, $\mathrm{C}=$ manufacturing, $\mathrm{D}+\mathrm{E}=$ electricity gas steam and water supply and waste man., $\mathrm{F}=$ construction, $\mathrm{G}=$ whole sale and retail trade, $\mathrm{H}=$ transport and storage, $\mathrm{I}=$ accommodation and food services, $\mathrm{J}=$ information and communication, $\mathrm{K}=$ finance and insurance, $\mathrm{L}=$ real estate, $\mathrm{M}=$ scientific and technical activities, $\mathrm{N}=$ administrative and support activities, $\mathrm{O}=$ public administration, $\mathrm{P}=$ education, $\mathrm{Q}=$ health and social work, $\mathrm{R}=$ entertainment and recreation, $\mathrm{S}+\mathrm{T}+\mathrm{U}=$ other services.

The growth rate of labor productivity in the Turkish economy keeps around three percent 
during the period of 2004-2017 (Table 2). The results also indicate that structural change contributes relatively little to productivity growth. More generally, the structural change in all subperiods seems to bring a drag on aggregate labor productivity growth, rather than a bonus. The dynamic shift effect has a negative contribution to the aggregate productivity growth during the sub-periods of (2004-2008) and (2010-2017) and the entire period of (2004-2017). That means that more productive industries could not maintain their employment shares.

Table 2

Decomposition of Labor Productivity in the Turkish Economy

(Average annual growth rates)

\begin{tabular}{cccccc}
\hline & $\begin{array}{c}\text { Labor Productivity } \\
\text { Growth }\end{array}$ & $\begin{array}{c}\text { Within Growth } \\
\text { Effect }\end{array}$ & $\begin{array}{c}\text { Static Shift } \\
\text { Effect }\end{array}$ & $\begin{array}{c}\text { Dynamic Shift } \\
\text { Effect }\end{array}$ & $\begin{array}{c}\text { Total } \\
\text { effect }\end{array}$ \\
\hline $\begin{array}{c}2004-2008 \\
\%\end{array}$ & 3,33 & 1,93 & 1,71 & $-0,32$ & 3,33 \\
$2010-2017$ & & 58,1 & 51,5 & $-9,6$ & 100,0 \\
$\%$ & 3,71 & 2,37 & 5,01 & $-3,66$ & 3,71 \\
$2004-2017$ & & 58,1 & 51,5 & $-9,6$ & 100,0 \\
$\%$ & 2,91 & 1,91 & 4,77 & $-3,77$ & 2,91 \\
$\%$ & & 63,9 & 134,8 & $-98,6$ & 100,0 \\
\hline
\end{tabular}

Source: Authors' calculations with the data of the Turkish Statistical Institute.

The positive static effect refers to the labor movements from less productive to more productive sectors, due to the policies that aimed to improve the economic infrastructure on one hand and on the other one: the high schooling rate, the high female labor force participation rate and the labor force migrating from rural areas. On the contrary, Turkey experienced labor transformations from more productive to less productive sectors during the period of (2010-2017). The interpretation for the inverse structural changes maybe the increasing informality which considered as a barrier to creating longer capital-work relationships and accumulating more experiences. Another possible interpretation may be the side effects of active employment policies that have been applied during these periods to combat high unemployment rates that resulted in some sorts of resource misallocations. Finally, economic growth can be achieved through the within-sector enhancements in labor productivity and the reallocation of labor force towards sectors with higher value added. In manufacturing, the within-sector effect accounts for the major part of aggregate productivity gains with a small structural change effect.

\section{Conclusion}

This study makes use of the conventional shift-share analysis in order to decompose 
aggregate labor productivity growth into two components: the first one is the within growth effect and the second component is the effect of the structural change which captures productivity growth stemmed from labor reallocation across sectors. The within productivity growth and structural change must go hand in hand in the development process. The results suggest that the within-sector effect (positive or negative) accounts for the major parts of aggregate productivity gains. The effect of structural change on productivity growth, on the other hand seems to be very small for all periods.

From this analysis we can conclude that both the shift of the qualified labor resources towards more productive industries and investment in fundamentals that support physical and human capital formation, innovation activities and infrastructure are essential for productivity growth. Service industries with still low productivity are attracting a significant amount of the labor force released from rural areas and more productive sectors. Primary industries reduce their value added and employment share in the period. In this period the Turkish economy get more integrated with the global economy. Intensified competition of trade liberalization forced low productivity manufacturing firms to exit the industry and only high productivity firms can survive. Labor released from these exiting firms usually flow to low productivity service or informal sectors of the economy. The rationalization effect of trade liberalization in many case studies ends up with growth reducing structural change (Rodrik, 2010).

The increase in informality and the active employment policies may be other explanations for the inverse structural change in the Turkish economy. The active employment (nonselective) policies that have been applied during these periods to combat high unemployment rates resulted in some sorts of resource misallocations. Additionally, the domestic economic crises of 2000-2001 and the global economic crisis of 2008 might have some disruptive effects on structural change and productivity growth. 


\section{References}

Acemoğlu, D., \& Guerrieri, V. (2008). Capital deepening and non-balanced economic growth. Journal of Political Economy 116(3), 467-498.

Acemoğlu, D. \& Üçer, M. (2015). The ups and downs of Turkish growth, 2002-2015: Political dynamics, the European Union and the institutional slide. NBER Working Paper No. 21608, October 2015.

Alvarez-Cuadrado, F., Van Long, N., \& Poschke, M. (2017). Capital-labor substitution, structural change and growth. Theoretical Economics 12(3), 1229-1266.

Atiyas, İ. (2010). Recent Privatization of Turkey: A Reappraisal. In Z. Öniş \& F. Şenses (eds.), Turkey and the Global Economy: Neo-Liberal Restructuring and Integration in the PostCrisis Era, Routledge Studies in Middle Eastern Economies.

Balkır, C. (1993). Turkey and the European Community: Foreign Trade and Direct Foreign Investment in the 1980s. In C. Balkır \& A. M. Williams (Eds.), Turkey and Europe (pp. 100-139). Pinter Publishers Ltd. London, U.K.

Baily, M. N., Bartelsman, E. J. and Haltiwanger, J. C. (2001). Labor productivity: structural change and cyclical dynamics. Review of Economics and Statistics, 83(3), 420-433.

Herrendorf, B., Herrington, C., \& Valentinyi, Á. (2015). Sectoral technology and structural transformation. American Economic Journal: Macroeconomics, 7(4), 858-860.

Krüger, Jens, J. (2008). Productivity and structural change: A review of the literature. Journal of Economic Surveys, 22(2), 330-363.

Lin, J. \& Yi-fu. (2012). New Structural Economics: A Framework for Rethinking Development and Policy. Washington, DC: World Bank.

Matsuyama, K. (2008). Structural Change. In S.N. Durlauf \& L.E. Blume (eds.), The New Palgrave Dictionary of Economics, 2 ed., Palgrave Macmillan.

McMillan, M., \& Rodrik, D. (2011). Globalization, Structural Change and Productivity Growth. P:2-12. NBER Working Paper No. 17143.

Öniş, Z., \& Rubin, B. (2004). The Turkish Economy in Crisis Critical Perspectives on the 20001 Crises, Routledge.

Öniş, Z. \& Şenses, F. (2010). The New Phase of Neo-Liberal Restructuring in Turkey: An Overview. In Z. Öniş \& F. Şenses (eds.), Turkey and the Global Economy: Neo-Liberal Restructuring and Integration in the Post-Crisis Era, Routledge Studies in Middle Eastern Economies.

Rodrik, D. (2010). Structural Transformation and Economic Development, TEPAV, ISBN: 9789944-927-42-0.

Retrieved

from https://www.tepav.org.tr/upload/files/12935384464.Yapisal_Donusum_ve_Iktisadi_Kalkinma.pdf 
Rodrik, D., McMillan M. \& Sepulveda C. (2016). Structural Change, Fundamentals, and Growth: A Framework and Case Studies. Washington, DC. International Food Policy Research Institute. 81-100.

Sachs, J. D., \& Warner, A. M. (2001). Natural resources and economic development: The curse of natural resources. European Economic Review, 45, 827-838.

Summers, R. (1985). Services in the International Economy. In R.P. Inman (eds.) Managing the Service Economy. Cambridge: CUP. pp. 27 - 48.

Syrquin, M. (2010). Kuznets and Pasinetti on the study of structural transformation: Never the Twain shall meet? Journal of Structural Change and Economic Dynamics, 21(4), 248-257.

Szirmai, A. (2012). Industrialization as an engine of growth in developing countries, 1950-2005. Structural Change and Economic Dynamics, 23(4), 406-420.

Tregenna, F. (2014). A new theoretical analysis of de-industrialization. Cambridge Journal of Economics, 38(6), 1373-1390.

Tuncer, İ., \& Altiok, M. (2013). Türkiye İmalat Sanayinde Yapısal Değişim ve Üretkenlik: 1980 2008 Dönemi. Anadolu Üniversitesi Sosyal Bilimler Dergisi, 13(2), 65-66.

UNIDO (2013). Sustaining employment growth: the role of manufacturing and structural change, 15-34. UNIDO, Vienna. Retrieved from: https://www.unido.org/sites/default/files/201312 /UNIDO_IDR_2013_main_report_0.pdf 